\title{
TATA KELOLA KEBIASAAN BARU DI TAMAN SUNGAI MUDAL YOGYAKARTA (Proses Adaptasi, Sosialisasi, Partisipasi oleh Pengelola dan Pengunjung)
}

\author{
Dyaloka Puspita Ningrum \\ Program Studi Ilmu Komunikasi, Fakultas Ilmu Sosial dan Ilmu Politik, \\ Universitas Widya Mataram Yogyakarta \\ Email: dyalokapuspita@yahoo.co.id
}

\begin{abstract}
ABSTRAK
Pandemi Covid-19 memberikan dampak yang signifikan terhadap sektor pariwisata karena banyak destinasi wisata yang tutup dan tidak dapat beroperasi secara maksimal. Tatanan kebiasaan baru menjadi alternatif kehidupan di masa depan yang tentu saja harus didasari dengan penerapan protokol kesehatan berdasarkan Keputusan Menteri Kesehatan RI Nomor : HK.01.07/Menkes/382/2020. Dibukanya kembali destinasi wisata harus didasari dengan tanggung jawab yang penuh oleh para pemangku kebijakan ataupun para pelaku wisatanya, termasuk di objek wisata Taman Sungai Mudal Yogyakarta. Penelitian ini bertujuan untuk mengetahui "Tata Kelola Kebiasaan Baru yang Dilakukan oleh Pengelola maupun Pengunjung di Objek Wisata Taman Sungai Mudal Yogyakarta" dengan menggunakan pendekatan partisipasi dan metode kualitatif deskriptif. Tata kelola adaptasi kebiasaan baru sebagai acuan operasional di objek wisata Taman Sungai Mudal pada prinsipnya sudah disesuaikan dengan panduan CHSE (cleanliness, health, safety, and environment sustainability), meskipun masih belum begitu maksimal. Pemerintah sebagai salah satu bagian dari stakeholders pariwisata harus berperan ganda, yang tidak hanya membuat regulasi untuk mengatur kegiatan pariwisata dengan himbauan penerapan protokol kesehatan, namun juga dapat mengevaluasi pelaksanaan kegiatan tersebut sebagai salah satu langkah strategis yang berorientasi terhadap keselamatan bersama. Mengembangkan partisipasi dan dukungan dari para pemangku kebijakan sejatinya mendorong iklim yang kondusif dalam perencanaan pembangunan pariwisata yang unggul disuatu wilayah.
\end{abstract}

Kata kunci: Kebiasaan Baru, Taman Sungai Mudal, Partisipasi Pengelola dan Pengunjung, Pandemi Covid-19.

\begin{abstract}
The Covid-19 pandemic has had a significant impact on the tourism sector because many tourist destinations are closed and cannot operate optimally. The new habit order becomes an alternative for life in the future which of course must be based on the application of health protocols based on the Decree of the Minister of Health of the Republic of Indonesia Number: HK.01.07/Menkes/382/2020. The reopening of tourist destinations must be based on the full responsibility of the policy makers or tourism actors, including the Yogyakarta Mudal River Park tourist attraction. This study aims to determine "New Habit Management Performed by Managers and Visitors at the Taman Sungai Mudal Tourism Object in Yogyakarta" by using a participatory approach and descriptive qualitative methods. The management of the adaptation of new habits as an operational reference at the Mudal River Park tourist attraction has in principle been adapted to the CHSE (cleanliness, health, safety, and environment sustainability) guidelines, although it is still not optimal. The government as one part of the tourism stakeholders must play a dual role, which is not only making regulations to regulate tourism activities with an appeal for the application of health protocols, but can also evaluate the implementation of these activities as one of the strategic steps oriented towards mutual safety. Developing participation and support from policy makers actually encourages a conducive climate in planning for superior tourism development in an area.
\end{abstract}

Keywords: New Normals, Mudal River Park, Management and Visitor Participation.

\section{PENDAHULUAN}

Kegiatan pariwisata di Indonesia yang multisektor memang cukup menjanjikan dan menjadi magnet bagi para wisatawannya. Namun di masa transisi saat ini, membuka sektor pariwisata di tengah pandemi sesungguhnya memang berisiko tinggi, sehingga banyak tempat wisata yang mengalami kerugian dan harus tutup karena tidak dapat beroperasi secara maksimal.
Kerja sama yang kondusif sangat dibutuhkan dari semua pihak, khususnya dari para stakeholders pariwisata itu sendiri yaitu: pemerintah, swasta dan masyarakat untuk tidak tergesa-gesa memulihkan keadaan ini seperti semula lagi utamanya akan tetap dapat dikontrol dengan baik. Ada banyak hal penting yang harus diperhatikan mulai dari: protokol kesehatan, akomodasi, infrastruktur, transportasi, maupun fasilitas yang ada di area wisata tersebut. 
Konsep kebiasaan baru / new normal yang dinantikan oleh banyak orang, hadir sebagai alternatif untuk memberikan kembali harapan kehidupan di masa depan. Fase new normal tentu saja harus didasari dengan pelaksanaan protokol kesehatan yang benar dan adanya kedisiplinan yang tinggi dari publik berdasarkan Keputusan Menteri Kesehatan RI Nomor: HK.01.07/Menkes/382/2020.

Menyikapi fase kenormalan baru dengan segala persiapan di setiap destinasi wisata, tentu harus didasari dengan tanggung jawab yang penuh oleh para pemangku kepentingan ataupun para pelaku wisatanya. Slogan "Ingat Pesan Ibu/3M (Mencuci tangan dengan sabun, Menggunakan masker, dan Menjaga jarak hindari kerumunan)" menurut Juru Bicara Satgas Penanganan Covid-19 yaitu Wiku Adisasmito saat Konferensi Pers di Kantor Presiden (tanggal 17 September 2020):

adalah sebuah kampanye yang belakangan ini muncul di ruang publik sebagai upaya mengendalikan dan meyakinkan masyarakat untuk menekan angka penyebaran virus yang masih belum ditemukan vaksin penyembuhannya tersebut. Protokol kesehatan harus menjadi kebiasaan bukan karena kewajiban terhadap aturan, undang-undang ataupun hukum yang berlaku (dalam liputan 6.com, di akses pada tanggal 25 november 2020).

Spirit berwisata terus disebarluaskan sebagai trend, terutama atas motif rasa ingin tahu publik yang terus meningkat dan mencuri perhatian banyak orang khususnya di beberapa destinasi wisata yang sifatnya "viral" atau bahkan "hidden". Selama masa pandemi juga banyak destinasi wisata yang melakukan pembenahan untuk mematangkan pertumbuhan pariwisatanya. Di saat itulah juga, ketidaksengajaan promosi terhadap objek-objek wisata, baik yang ada di perkotaan maupun di perdesaan sangat gencar digaungkan. Fenomena yang muncul justru memperlihatkan panorama pariwisata berdasarkan pengalaman dan perjalanan seseorang yang telah terdokumentasikan di waktu lampau.

Dibukanya kembali destinasi wisata dalam sistem kebiasaan baru diharapkan dapat mendukung para pelaku usaha wisata, seperti: pebisnis besar, sektor usaha kecil dan menengah ataupun sektor tenaga kerja musiman yang dirumahkan/sempat vakum beberapa waktu silam.

Pemanduan dan pengawasan kebiasaan baru di setiap destinasi wisata, tentunya memang diprioritaskan untuk daerah yang sudah dinyatakan siap dibuka dan harus saling terkoordinasi dengan Gugus Tugas Covid-19 maupun Kepala Daerah wilayah masingmasing. Bahkan di tengah masa adaptasi sekarang ini, ada beberapa model baru berwisata yang dikenalkan dan dapat dilakukan oleh wisatawan seperti: solo traveling, wellness tour, walking tour, virtual tour serta staycation.

Implementasi kebiasaan baru mulai dari sosialisasi, simulasi dan uji coba pada sektor pariwisata harus diiringi dengan rangkaian mitigasi bencana untuk tetap dapat menjaga keselamatan dan kesehatan publik sebagai urgensi di era sekarang ini. Adaptasi kebiasaan baru adalah bentuk himbauan dari pemerintah, sosialisasi menjadi sebuah keharusan, dan partisipasi dari semua komponen sosial sangat diharapkan guna mencapai pembangunan pariwisata yang berkelanjutan.

Kebijakan pemerintah menerapkan adaptasi kebiasaan baru tentu akan membuat perekonomian bangkit lagi bila hal itu di iringi dengan kebijakan yang tepat, namun bila sebaliknya maka kebijakan ini akan menimbutkan potensi penyebaran Covid-19 semakin masif dan berbahaya. Kondisi ini juga akan mempengaruhi perkembangan ekonomi dan juga tingkat kepercayaan masyarakat terhadap pemerintah akan dipertaruhkan, selain juga kebijakan yang ideal tentu harus diiringi dengan implementasi kebijakan yang yang medukung, pengawasan yang ketat juga akan menentukan pelaksanaan kebijakan ini terlaksana dengan baik sesuai dengan kebijakan yang ada (Sumarni, 2020).

Yogyakarta merupakan salah satu kota besar di Indonesia yang cukup popular dengan ikonnya sebagai kota wisata. Namun hampir semua destinasi wisata yang ada di Yogyakarta selama pandemi Covid-19 pun turut terkena imbasnya termasuk pada objek ekowisata Taman Sungai Mudal. Ekowisata Taman Sungai Mudal merupakan salah satu destinasi wisata air dengan pesona alam yang begitu menawan, terletak di kawasan Pegunungan Menoreh Dusun Banyuganti Kecamatan Girimulyo Kabupaten Kulon Progo Yogyakarta.

Taman Sungai Mudal memiliki kolam pemandian yang airnya masih sangat jernih dan berwarna biru toska, bahkan objek wisata ini terletak di paling puncak dari beberapa aliran wisata air lainnya seperti: Air Terjun Kembang Soka serta Air Terjun Kedung Pedut. Selain itu, objek ini pun menyediakan berbagai fasilitas umum lainnya berupa kamar mandi, kamar 
ganti, mushola, warung makan, gazebo untuk beristirahat, akses internet gratis, serta wahana flying fox maupun camping ground yang dikelola secara swadaya untuk membantu meningkatkan perekonomian masyarakat setempat (https://dinpar.kulonprogokab. go.id/ekowisata-sungai-mudal.html, diakses pada tanggal 22 Desember 2020).

Destinasi wisata yang satu ini cukup popular karena sering didatangi oleh banyak publik figur melalui aktivitas berwisatanya di beberapa media sosial khususnya. Dalam hal ini menentukan platform digital seperti media sosial Facebook, Instagram, Youtube, Twitter atau bahkan Tiktok yang sudah banyak digunakan oleh para pelaku wisata dapat juga digunakan sebagai alat promosi terhadap target market tertentu karena dinilai memiliki potensi cukup tinggi (Situmeang, 2020). Dalam menghadapi kebiasaan baru, proses adaptasi-pun diberlakukan pada objek wisata Taman Sungai Mudal. Para pengelola melakukan penyemprotan cairan desinfektan, pengecekan suhu tubuh, pendataan identitas pengunjung, menyiapkan tempat cuci tangan, mewajibkan penggunaan masker, serta menyiapkan tisu kering dan hand sanitizer di loket kedatangan sebagai strategi berwisata yang sehat dan aman dari Covid-19 (Hasil Penelitian di Lapangan, Pada Bulan September Tahun 2020).

Beradaptasi dengan kebiasaan baru di masa transisi saat ini adalah bentuk kesadaran publik yang hampir diterapkan pada semua lini kehidupan. Secara tidak langsung juga, perlahan-lahan perubahan tersebut menjadi suatu gaya hidup/budaya di masyarakat. Mulai dari membiasakan diri untuk berolahraga, mencuci tangan dengan sabun sebelum dan sesudah beraktivitas, menggunakan masker dan hand sanitizer, mengonsumsi buah segar dan vitamin, serta beberapa perilaku produktif lainnya yang secara intens sudah dilakukan dalam rutinitas sehari-hari

Keidentikan Taman Sungai Mudal sebagai objek wisata air secara spesifik menghadirkan risiko/kekhawatiran tersendiri karena dapat menciptakan titik berkumpulnya banyak orang di dalam satu tempat yang sama. Sehingga kondisi yang padat tentu saja bertentangan dengan anjuran physical distancing ataupun dengan konsep berwisata yang aman dan sehat.

Filterisasi terhadap jumlah wisatawan yang datang di suatu objek wisata sangat penting dilakukan untuk memberikan jaminan maupun keselamatan kepada wisatawan agar tidak berdampak pada lingkungan atau bahkan turut meninggalkan musibah bagi warga lokalnya, termasuk pada objek wisata Taman Sungai Mudal Yogyakarta.

Mengkritisi keadaan tersebut, semua elemen harus dapat saling bersinergi menjaga sektor wisata terkait dengan kewajiban, tanggung jawab dan peran untuk mensukseskan peran serta Kelompok Sadar Wisata (Pokdarwis) saat ini harus diaplikatifkan menjadi Masyarakat Sadar Wisata (Masdarwis). Meskipun terlihat bahwa kebijakan pemerintah telah banyak dikomunikasikan untuk merealisasikan kesiapan sektor pariwisata di berbagai destinasinya. Penelitian ini bertujuan untuk mengetahui "Tata Kelola Kebiasaan Baru terhadap Destinasi Wisata, Khususnya dalam Proses Adaptasi, Sosialisasi, dan Partisipasi Pengelola maupun Pengunjung di Taman Sungai Mudal Yogyakarta" dengan menggunakan pendekatan partisipasi yang difokuskan pada partisipasi semua pihak untuk meningkatkan kepedulian serta kesadaran dalam kegiatan kepariwisataan pada tatanan kebiasaan baru.

\section{KAJIAN PUSTAKA}

\subsection{Tata Kelola}

Tata kelola menurut (Amnah dkk, 2016:7) diartikan sebagai pengelolaan urusan kepemerintahan yang melibatkan ketiga unsur yaitu pemerintah, masyarakat, dan swasta dalam segala bidang. Paradigma ini mengutamakan mekanisme dan proses dimana para warga masyarakat dan kelompok dapat mengartikulasikan kepentingannya, memediasi berbagai perbedaan-perbedaannya, dan menjalankan hak dan kewajibannya untuk mencapai manfaat pembangunan yang dapat dirasakan semua pihak.

\subsection{Kebiasaan Baru / New Normal}

Kebijakan tatanan kebiasaan baru/new normal didasari oleh pernyataan Badan Kesehatan Dunia (WHO) yang mengungkapkan bahwa Covid-19/ (Coronavirus Disease-2019) tidak akan hilang dalam waktu singkat. Kementerian Kesehatan Republik Indonesia menerbitkan aturan kebiasaan baru yang harus dipatuhi oleh masyarakat ketika akan bepergian keluar rumah berdasarkan SOP protokol kesehatan untuk menekan dampak negatif yang utamanya diantisipasi dengan empat standar, yakni (1) kebersihan, (2) kesehatan, (3) keselamatan, dan (4) kepedulian lingkungan yang terjamin.

Secara umum kebiasaan baru merupakan sebuah cara dalam menjalani kehidupan sehari-hari yang dilaku- 
kan dengan membudayakan hidup bersih dan sehat melalui gerakan (3M), yaitu mencuci tangan, menggunakan masker, serta menjaga jarak dan menghindari kerumunan.
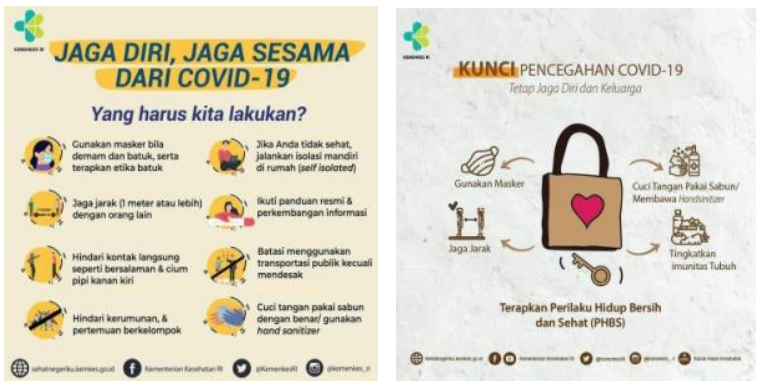

Gambar 1. Infografis Kebiasaan Baru (Sumber: Instagram @kemenkes_ri, diakses pada tanggal 25 Desember 2020)

Di era keberlimpahan informasi saat ini, publik dapat mengakses panduan protokol kesehatan tersebut melalui situs resmi pemerintah guna mewujudkan adapatasi kebiasaan baru dalam setiap rutinitasnya.

Di sisi lain, adaptasi kebiasaan baru itu sendiri harus disertakan juga dengan kegiatan sosialisasi sebagai suatu keharusan dalam membangun kesadaran dan kepatuhan semua elemen masyarakat untuk melaksanakan protokol kesehatan. Sosialisasi itu sendiri harus menjelaskan apa saja yang harus dilakukan dan dihindari selama masa adaptasi kebiasaan baru dalam masa pandemi covid-19, termasuk hadirnya gerakan/ kampanye di berbagai platform digital dengan hastag seperti: \#SiapUntukSelamat, \#BersatuLawanCovid 19, \#CuciTangan, \#JagaJarak, \#MaskerUntukSemua, \#TidakMudik, \#DiRumahAja (https://covid19.go.id/p/ berita/tantangan-adaptasi-kebiasaan-baru-dalambudaya-masyarakat-indonesia, diakses pada tanggal 22 Desember 2020).

\subsection{Teori Partisipasi}

Teori pendukung yang digunakan dalam penelitian ini yaitu teori sosial masyarakat: teori partisipasi. Dalam Peraturan Menteri Dalam Negeri Nomor 5 Tahun 2007 , partisipasi pada dasarnya merupakan keterlibatan masyarakat dalam proses penentuan arah dari strategi kebijaksanaan pembangunan yang dilaksanakan oleh pemerintah. Pembangunan sebenarnya merupakan suatu proses perubahan yang direncanakan dan dikehendaki.

Sumaryadi I Nyoman (2010 :46) mengartikan partisipasi sebagai peran serta seseorang atau kelompok masyarakat dalam proses pembangunan baik dalam bentuk pernyataan maupun dalam bentuk kegiatan dengan memberi masukan pikiran, tenaga, waktu, keahlian, modal dan atau materi, serta ikut memanfaatkan dan menikmati hasil - hasil pembangunan. Sedangkan Shadily (2000:31) mengemukakan bahwa masyarakat adalah suatu kelompok dari berbagai golongan yang saling mempengaruhi. Di dalam penelitian ini sangat dibutuhkan partisipasi dari pengelola maupun pengunjung di objek wisata Taman Sungai Mudal sebagai pelaku wisata yang tetap beradaptasi dengan aman dan sehat.

\section{METODE PENELITIAN}

Penelitian ini menggunakan metode kualitatif dengan pendekatan deskriptif yang dilaksanakan pada objek wisata Taman Sungai Mudal Dusun Banyuganti Kecamatan Girimulyo Kabupaten Kulon Progo Yogyakarta. Informan ditentukan dengan menggunakan teknik purposive, yaitu para pengelola dan pengunjung di objek wisata Taman Sungai Mudal sebagai pihak-pihak yang terlibat dalam pelaksanaan tata kelola kebiasaan baru pada sektor pariwisata.

Dipilih sebagai lokasi penelitian dengan beberapa pertimbangan, antara lain: (1) Sebagai salah satu objek wisata air yang cukup vital di masa adaptasi kebiasaan baru saat ini, karena dapat menyebabkan berkumpulnya banyak orang di satu tempat yang sama, (2) Harga tiket masuk yang sangat terjangkau, membuat objek wisata tersebut selalu ramai didatangi banyak pengunjung, dan (3) Branding objek wisata Taman Sungai Mudal di berbagai platform media sosial terus menjadi tren di kalangan kaum muda.

Teknik pengumpulan data dalam penelitian ini menggunakan metode observasi, wawancara dan studi dokumentasi. Tidak lupa peneliti menganalisis data dengan cara reduksi data, penyajian data dan penarikan kesimpulan. Uji keabsahan data dilakukan melalui teknik triangulasi sumber, dengan mengumpulkan dan menguji data yang telah diperoleh dilakukan langsung ke para pengelola, para pengunjung yang datang ke lokasi penelitian, ataupun pihak pemerintah dalam mendukung kebijakan adaptasi kebiasaan baru terutama pada objek wisata Taman Sungai Mudal.

\section{HASIL DAN PEMBAHASAN}

\subsection{Temuan di Lapangan}

Pariwisata yang berdamai dengan pandemi dalam kenyataannya masih perlu mendapat perhatian yang lebih mendalam dari para pemangku kebijakan 
maupun para pelaku wisata itu sendiri. Menariknya untuk tetap mendukung perekonomian masyarakat, alternatif adaptasi kebiasaan baru/new normal terus digaungkan dengan syarat mengedepankan protokol kesehatan / prokes yang disiplin dan tentunya juga sudah mendapatkan rekomendasi dari pemerintah termasuk pembukaan kembali di Ekowisata Taman Sungai Mudal Yogyakarta.

Penerapan prokes di objek wisata Taman Sungai Mudal terlihat di beberapa titik lokasi kedatangan seperti parkiran, loket tiket, kantin, mushola, bantaran sungai, dan beberapa tempat lainnya. Kegiatan pariwisata yang ada di kabupaten ataupun di kota Jogja dalam rangka masa adaptasi kebiasaan baru, secara operasional memang terlihat cukup berbeda dari sebelumnya. Dalam hal ini, para pengelola objek wisata Taman Sungai Mudal bahkan menerapkan pembatasan jam kunjungan bagi para pengunjung dilokasi tersebut setiap hari, mulai dari pukul $08.30-15.15$ WIB.

Sebagai salah satu ekowisata yang fokus memberdayakan masyarakat lokalnya, objek wisata Taman Sungai Mudal sekarang ini memiliki karyawan sebanyak 70 orang. Para pengelola objek wisata Taman Sungai Mudal berupaya up to date dalam memberikan informasi terkait aktivitas yang dilakukan oleh para pengunjung, terutama melalui media sosial instagram dengan real akun pengguna @ sungaimudal dengan jumlah followers/pengikut sebanyak 3.163 orang (berdasarkan data pengikut yang ada di akun instagram @sungaimudal, diakses pada tanggal 14 Juni 2021).

Tidak hanya aktif pada media sosial instagram, para pengelola khususnya kru di bagian publikasi setiap harinya sangat gencar melakukan kegiatan rutin liputan promosi di beberapa platform digital lainnya, seperti: twitter, blog ataupun website, sebagai bagian dari salah satu strategi pengelolaan yang tepat di era digital marketing communication demi meningkatkan jumlah kunjungan wisatawan yang sempat mengalami penurunan drastis selama masa lockdown beberapa waktu belakang. Selain itu media sosial pun dapat menjadi media pemasaran dapat lebih efektif dan efisien dalam menjangkau pangsa pasar yang lebih luas jika memiliki strategi pengelolaan yang inovatif (Teguh et al, 2020).

Pada masa adaptasi kebiasaan baru ini juga, objek wisata Taman Sungai Mudal yang para pengelolanya merupakan penduduk asli di daerah tersebut mau tidak mau harus menaikan harga retribusi masuk yang semula seharga Rp 6.000 menjadi Rp 10.000 per orang. Peningkatan biaya tersebut sebagai subsidi guna membantu pemasokan bahan prokes untuk para pengunjung yang datang, meliputi pembelian : hand sanitizer, tisu kering, sabun cuci tangan, serta cairan penyemprot desinfektan karena kurangnya bantuan operasional dari pemerintah dalam memberikan stimulus ekonomi terhadap para pengelola di objek wisata Taman Sungai Mudal, tidak memutuskan semangat kerja petugas yang ada untuk terus berupaya menjaga kestabilan kegiatan pariwisata di destinasi tersebut.

Para pengunjung yang datang dan berasal dari luar maupun dalam kota wajib melakukan pendataan melalui tanda pengenalnya masing-masing (misal: KTP \& SIM) yang kemudian diakses oleh para pengelola melalui aplikasi online yaitu "Visiting Jogja" sebagai kontrol yang berkoordinasi secara langsung dengan Dinas Pariwisata Kabupaten Kulon Progo, meskipun diakui para pengelola hal ini masih belum begitu menjamin pencegahan penyebaran Covid-19 di objek wisata Taman Sungai Mudal.

Awalnya, pendataan kunjungan wisatawan dilakukan dengan menggunakan sebuah handphone genggam yang sengaja dibeli oleh pengelola. Namun seiring berjalannya waktu membuat pendataan tersebut sekarang ini lebih cenderung dilakukan secara manual/ tulis tangan karena alat komunikasi yang dimiliki mengalami kendala / kerusakan.

Ada beberapa langkah prioritas yang dilakukan para pengelola objek wisata Taman Sungai Mudal dalam menjamin kebersihan, kenyamanan, dan keamanan pengunjungnya, terutama pada pembangunan prasarana seperti renovasi jembatan yang menjadi sarana hubung dari satu tempat ke tempat lain di lokasi tersebut.

Selain itu ada juga penambahan gazebo dan sterilisasi pengunjung yang sangat diperketat dengan batas akhir aktivitas pemandian pada pukul $16.00 \mathrm{WIB}$. Serta adanya ruang isolasi pengujung sebagai salah satu tempat yang sengaja disiapkan oleh Dinas Pariwisata Kabupaten Kulon Progo serta Badan Otorita Borobudur untuk menyaring para pengunjung yang memiliki suhu tubuh diatas 37 derajat $\mathrm{C}$.

Namun memang, dari sisi keselamatan pengunjung sendiri diakui para pengelola di objek wisata Taman Sungai Mudal masih belum begitu memadai. Sejauh ini dalam hal pencegahan risiko kecelakaan ataupun cidera berwisata pengunjung hanya mengandalkan kru medis dengan perlengkapan kotak P3K saja. 

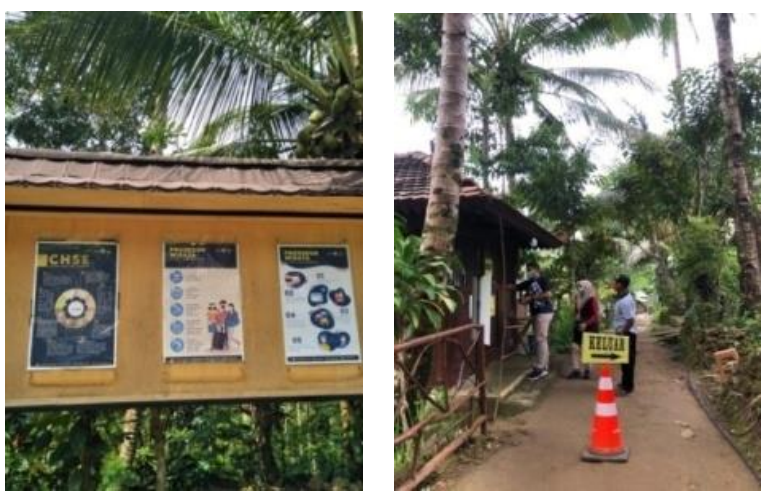

Gambar 2. Panduan Protokol Kesehatan di Objek Wisata Taman Sungai Mudal (Sumber: Hasil Penelitian di Lapangan, diakses pada tanggal 10 April 2021)

Para pengunjung yang mendatangi objek wisata Taman Sungai Mudal juga tetap perlu memperhatikan kewaspadaan terhadap kondisi air terjun di kawasan tersebut, karena berada pada hamparan alam terbuka yang kapan saja faktor cuaca salah satunya menjadi ancaman dan ketidakamanan bagi para wisatawan. Dalam kondisi sekarang ini, objek wisata Taman Sungai Mudal memang harus mengurangi jumlah kunjungan yang tidak sama layaknya hari-hari biasa dengan batas penuh pengunjung paling banyak maksimal 400 orang.

Secara geografis kehadiran objek wisata Taman Sungai Mudal dapat dijadikan sebagai bagian dari program pembangunan Desa Giri Mulyo karena mampu memberikan ruang pekerjaan baru terhadap masyarakat marginal yang berlatar belakang perekonomian ke bawah. Dengan menjunjung nilai kearifan lokal seperti gotong royong ataupun musyawarah mufakat, struktur kepengurusan pengelolaan di objek wisata Taman Sungai Mudal yang sudah disepakati secara kolektif itupun, terus memberikan kesempatan terhadap warga lainnya untuk dapat berpartisipasi dan ikut serta pada proses perekrutan keanggotaan, terutama dalam mengembangkan potensi sumber daya alam di daerah tersebut.

Objek wisata yang pertama kali dibuka untuk umum tahun 2015 ini, berangkat dari inisiatif warga setempat karena melihat potensi lingkungan yang sehari-hari digunakan sebagai sumber pengaliran air minum bersih penduduk yang masih sangat asri dan sejuk dari puncak perbukitan khas mata airnya. Selain itu, objek wisata Taman Sungai Mudal juga terletak berdekatan dengan beberapa lokasi wisata lainnya yang ada di wilayah tersebut. Sehingga diteruskan menjadi sebuah destinasi wisata yang menyuguhkan pesona alam dengan atribut kepengurusan yang lengkap, mulai dari: pengawas, pembina, ketua, sekretaris, bendahara, dan beberapa kru kerja di setiap pokja-nya masing-masing (pokja keamanan, pokja wahana, pokja loket, pokja parkir, pokja bantaran sungai dan lainnya).
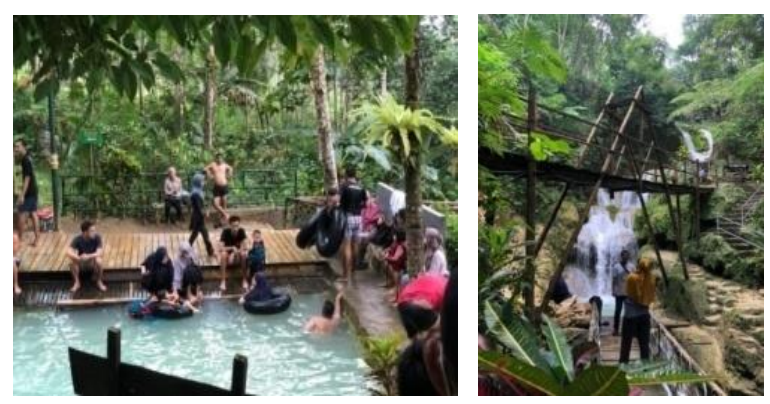

Gambar 3. Aktivitas Para Pengunjung di Objek Wisata Taman Sungai Mudal (Sumber: Hasil Penelitian di Lapangan, diakses pada tanggal 12 Juni 2021)

Motif lain kedatangan para pengunjung di objek wisata Taman Sungai Mudal di era sekarang ini karena tersedianya fasilitas yang memadai seperti koneksi wifi internet sehingga menjadi daya tarik tersendiri selain minat berwisata pada umumnya. Selain itu, terdapat kawasan favorit para pengunjung yang sering menghabiskan waktu bersama untuk sekedar bermain air, mandi, atau hanya ingin mengabadikan momen di pinggiran bantaran sungai.

Maraknya persaingan sektor pariwisata yang terus bermunculan di Yogyakarta tidak begitu mempengaruhi perkembangan objek wisata Taman Sungai Mudal, yang justru di masa sulit sekarang ini lebih banyak menjadi alternatif berwisatanya publik. Namun memang dalam mendukung kemajuan pariwisata yang berkelanjutan harus terus ditinjau secara tegas oleh pihak pemerintah terutama dari impelementasi protokol kesehatan. Diakui salah seorang pengelola di objek wisata Taman Sungai Mudal, bahwa memang pernah ada pelatihan ataupun seminar terkait penemuhan kebutuhan informasi pariwisata di era new normal namun secara keseluruhan tim yang bekerja dilokasi wisata itu sendiri belum mendapatkan tinjauan dan evaluasi yang begitu efektif.

Objek wisata Taman Sungai Mudal turut dijadikan juga sebagai ladang perekonomian bagi warga setempatnya. Ada sejumlah kantin kecil yang pada akhirnya dijadikan juga sebagai tempat berteduh ataupun tempat singgah para pengunjung yang datang, mulai dari sekadar beristirahat, menyantap jajanan ringan, menyewa ban renang/pelampung, ataupun sebagai kamar mandi dan tempat ganti pakaian pengunjung. Tidak ada bentuk larangan yang diberlakukan untuk 
para pedagang di objek wisata Taman Sungai Mudal. Hanya saja, mereka harus mengikuti aturan di masa adaptasi kebiasaan baru seperti menyediakan tempat cuci tangan, tempat sampah, serta memberikan batasan atau tanda di setiap tempat duduk agar wisatawan dapat saling menjaga jarak fisik antara satu dengan yang lain.

Vlog merupakan salah satu bentuk publikasi video yang kreatif, menarik dan sering dilakukan para pengunjung terutama di beberapa kolam pemandian yang jernih berwarna hijau tosca. Hal tersebut justru dianggap pengelola sebagai sebuah keuntungan dalam memasarkan destinasinya kepada para wisatawan. Tidak hanya berwisata, para pengunjung yang datang juga diajak beredukasi untuk menjaga kelestarian lingkungan karena terdapat beberapa jenis tanaman dan satwa yang cukup identik, diantaranya: anggrek, pakis, elang, reptil iguana, dan lainnya.

Tim Gugus Tugas Covid-19 daerah Kabupaten Kulon Progo yang bekerja sama dengan Satuan Polisi Pamong Praja (SATPOL PP) memang tidak secara rutin melakukan inspeksi mendadak di lokasi objek wisata Taman Sungai Mudal, namun keadaan yang seperti itu justru menjadi tantangan bagi para pengelola untuk terus memperketat penerapan adaptasi kebiasaan baru berwisata yang aman dan sehat bagi para pengunjungnya.

Pihak kepolisian dalam hal ini Polsek setempat bahkan turut membantu aktivitas pariwisata di objek wisata Taman Sungai Mudal, terutama dari sisi keamanan dan ketertiban lalu lintas para pengujung yang datang. Di beberapa kesempatan juga, mereka terus menghimbau wisatawan untuk tetap mematuhi prokes yang ada. Di sisi lain, ada beberapa saran yang disampaikan oleh para pengunjung yang datang khususnya mengenai keberadaan sampah bekas yang ada di sekitaran lokasi wisata yang ke depannya mungkin saja dapat dilakukan pengelolaan untuk kelestariaan ekosistem.

Bentuk swadaya masyarakat dan dukungan moril dari RW setempat adalah sumbangsih sosial yang biasa didapatkan para pengelola. Besar harapan yang digantungkan para pengelola objek wisata Taman Sungai Mudal terhadap pemerintah di masa adaptasi kebiasaan baru, terutama mengenai hal koordinasi dan peningkatan kegiatan kepariwisataan yang lebih maju lagi, karena secara disadari pun objek wisata tersebut terus menjadi tumpuan warga lokal dalam mengais perekonomian meskipun dalam kondisi sulit sekarang ini.

\subsection{Proses adaptasi, sosialisasi, partisipasi oleh pengelola dan pengunjung di objek wisata Taman Sungai Mudal}

Seiring waktu, kegiatan pariwisata sendiri terus menjadi perbincangan yang cukup kontradiktif di masa adaptasi baru karena pandemi yang terjadi masih belum menunjukkan titik terang, salah satunya terkait dengan kebijakan larangan mudik jilid 2 . "Mudik Dilarang, Tempat Wisata Dibuka Selama Libur Lebaran", wacana tersebut pada akhirnya menunjukkan kondisi di berbagai destinasi wisata yang cukup ramai dan dipadati oleh banyak wisatawan, sehingga hal itu pun menjadi sesuatu yang sangat membahayakan, ekstrimnya keadaan tersebut dapat menghadirkan sebuah klaster nyata di sektor pariwisata.

Termasuk di objek wisata Taman Sungai Mudal yang juga mengalami lonjakan kedatangan pengunjung tepatnya pada hari kedua lebaran Idul Fitri yang lalu. Motif berwisatanya para pengunjung pada tatanan kebiasaan baru tersebut, tentu saja berkaitan dengan kesiapan para pengelola di setiap lokasi wisata.

Keterbukaan informasi yang dijalankan dengan sebuah komunikasi publik bukan hanya sebatas publikasi terkait perkembangan informasi, kebutuhan, ataupun kebijakan yang akan dijalankan kedepannya, melainkan juga bagaimana strategi yang dilakukan pemerintah dalam membangun partisipasi aktif seluruh lapisan masyarakat untuk bersama-sama melaksanakan kegiatan berwisata yang aman sesuai dengan panduan CHSE (cleanliness, health, safety, and environment sustainability).

Protokol kesehatan/prokes 3M seperti mencuci tangan dengan sabun, menggunakan masker, dan menjaga jarak untuk para pengelola maupun para pengunjung yang datang sama halnya seperti pelaksanaan program komunikasi pemasaran (Ningrum et al., 2018) yang mana harus memiliki keunikan dan kekhasan tersendiri sebagai sebuah seruan kolektif dari setiap substansinya agar dapat memberikan hasil yang maksimal, sehingga menjadi acuan operasional objek wisata Taman Sungai Mudal guna memutus mata rantai penyebaran Virus Covid-19.

Kebijakan adalah salah satu tugas pemerintah yang tertuang dalam dua bagian yakni membuat kebijakan kemudian mengimplementasikan dalam bentuk pelayanan publik (Nugroho, 2018). Implementasi adaptasi kebiasaan baru dengan Panduan Protokol Kesehatan/3M yang ketat mampu menghasilkan se- 
buah gaya hidup baru di masyarakat dalam penyesuaian perilaku hidup sehat dan bersih sebagai bagian dari upaya persuasif maupun upaya preventif di masa sulit sekarang ini, meskipun hal tersebut belum dapat memberikan jaminan yang maksimal untuk segera mungkin pulih kembali menuju masa depan yang benar-benar normal. Gaya hidup yang mulai melekat di setiap aktivitas publik, dengan demikian menunjukkan suatu keberhasilan dari proses pembelajaran sosial masyarakat di tengah pandemi yang menghimpit.

Menelaah satu per satu panduan berwisata yang aman dan sehat di objek wisata Taman Sungai Mudal dapat dilihat dari kesiapan di setiap aspeknya agar dapat mewujudkan kegiatan pariwisata yang berkelanjutan. Tinjaun panduan protokol kesehatan di masa adaptasi baru dilihat dari aspek kebersihan, terdapat beberapa fasilitas penunjang yang sudah disiapkan para pengelola objek wisata, seperti tempat pencucian tangan dengan sabun cair, tisu kering, hand sanitizer, kotak sampah serta toilet ganti.

Sedangkan dari aspek kesehatan, semua pelaku wisata yang ada diperkenankan menggunakan masker di area yang terbuka. Selain itu terdapat juga pengecekan suhu tubuh menggunakan termogen dengan batas normal maksimal 37 derajat $\mathrm{C}$ dan tanda pengaturan jarak fisik yang diberlakukan, mulai dari loket tiket kedatangan ataupun di beberapa tempat peristirahatan, kantin/warung makan. Termasuk adanya ruang/tenda isolasi.

Di sisi lain, aspek keselamatan objek wisata Taman Sungai Mudal didukung dengan formasi tenaga kerja yang bertugas disetiap tempatnya lengkap dengan alat bantu HT/handy talky per-orang sebagai media berkomunikasi dan berkoordinasi antara satu dengan yang lain dalam memantau aktivitas para pengunjung yang datang.

Di beberapa titik juga terdapat papan petunjuk evakuasi yang membantu para pengunjung apabila terjadi bencana alam mengingat lokasi tersebut merupakan kawasan terbuka dengan dataran tinggi yang cukup membahayakan. Dan dari aspek kelestarian lingkungan sangat berkaitan dengan kondisi lingkungan di sekitar objek wisata Taman Sungai Mudal yang masih asri dan potensial. Warga setempat bahkan melakukan pemanfaatan sumber daya alam di lokasi tersebut sebagai bentuk konservasi terhadap ekosistem yang ramah lingkungan.

Pelaksanaan CHSE di objek wisata Taman Sungai Mudal sejatinya harus terus ditingkatkan, terutama melalui kesadaran dan partisipasi oleh semua pihak. Keadaan ini pun selaras dengan perspektif teori partisipasi, ada 2 bentuk tingkat partisipasi yang diberikan masyarakat dalam menyukseskan program adaptasi kebiasaan baru di objek wisata Taman Sungai Mudal, yaitu partisipasi bentuk nyata dan partisipasi bentuk tidak nyata/abstrak.

Berdasarkan analisis dari temuan peneliti di lapangan, tingkat partisipasi masyarakat yang sifatnya tidak nyata itupun tidak dapat dikatakan berjalan secara optimal, karena masih rendahnya kedisipilinan dari para pengunjung ataupun dari para pengelolanya sendiri untuk menjalankan kesungguhan adaptasi 3M secara konsisten, termasuk dalam hal ketidakpatuhan penggunaan masker di kawasan air terjun dan bantaran sungai.

Penggunaan masker tidak hanya formalitas semata. Melainkan juga dapat membantu publik untuk saling menjaga satu sama lain, sekalipun di kawasan wisata air. Kehadiran para pengunjung yang setiap waktunya silih berganti terutama di hari libur, membuat para pengelola sedikit lengah dalam mengawasi wisatawan yang datang untuk mencuci tangan terlebih dahulu sebelum menuju loket awal kedatangan. Sehingga kembali membuat beberapa sarana yang sudah disiapkan pada tatanan kebiasaan baru ini pun menjadi tidak efektif.

Berbagai kampanye yang telah digaungkan pun terhadap pola hidup yang bersih dan sehat, salah satunya dengan substansi protokol kesehatan rajin mencuci tangan, ternyata turut membuktikan sekadar retorika sosial saja. Kontrol di objek wisata Taman Sungai Mudal pun masih sangat minim. Bentuk partisipasi dari pengelola serta pengunjung sendiri tidak didasari dengan rasa tanggung jawab yang penuh dalam menuju keberhasilan pembangunan pariwisata yang berkelanjutan. Padahal memberlakukan protokol kesehatan adalah salah satu cara untuk menghindari risiko terpapar Covid-19, atau justru membawa pengaruh positif juga pada tatanan kepariwisataan walaupun belum sepenuhnya kembali seperti sediakala (Krisdayanthi, 2020).

Selain itu, keunikan objek wisata Taman Sungai Mudal diwarnai juga dengan beberapa kawasan darurat lainnya seperti jembatan penyebrangan ataupun kolam pemandian yang memang juga perlu disoroti dengan sangat seksama terutama dalam hal keamanan dan kesehatan para pengunjung.

Tidak adanya ukuran untuk batasan waktu mandi ataupun berenang para pengunjung di dalam kolam 
pemandian yang sama dan sering terpantau menimbulkan kerumuman sehingga sulit untuk dapat menjaga jarak fisik antara satu pengunjung dengan pengunjung yang lain, sama halnya dengan kegiatan camping ground di kawasan tersebut.

Selain bermain air, para pengunjung yang datang juga dapat merasakan sensasi berkemah di alam terbuka yang seiring waktu telah menjadi minat khusus kaum muda. Namun, lingkungan fisik area camping ground pada objek wisata Taman Sungai Mudal pun masih membutuhkan pembenahan. Memiliki akses tanah yang tidak begitu luas, beberapa tenda para pengunjung sering terpantau sangat berdekatan, terutama waktu di akhir pekan. Sehingga keadaan itupun menjadi hal yang tidak sesuai dengan aturan protokol kesehatan di masa adaptasi kebiasaan baru sekarang ini. Lemahnya kesadaran para pengunjung dalam berwisata maupun inisiatif dari pengelolanya sendiri, menunjukkan ketidakseriusan atas sistem yang sedang dibangun.

Di sisi lain, bentuk partisipasi nyata dalam berwisata di masa adaptasi kebiasaan baru juga tercermin dalam wujud fisik seperti uang, benda ataupun tenaga manusia di objek wisata Taman Sungai Mudal yang dapat dijalankan dengan suatu pendekatan dengan mengutamakan nilai kearifan lokal, khususnya melalui peran para pengelola yang bertugas di destinasi wisata tersebut sebagai bagian dari dimensi murni proses pembangunan daerah. Bantuan dana sosial secara sukarela yang rutin diberikan oleh warga di pemukiman sekitar pun turut membantu nafas dan partumbuhan ekowisata air ini untuk terus berupaya memperbaiki sarana dan prasarana yang ada.

Kegiatan gotong royong dengan aktivitas bersihbersih di lokasi wisata setiap harinya menjadi program handalan yang sering dilakukan oleh para pengelola terutama di masa adaptasi kebiasaan baru sebagai pengutan protokol kesehatan di obejk wisata tanan sungai mudal khususnya. Beberapa mitra terdekat pun turut membantu dalam menertibkan protokol kesehatan terhadap para pengunjung yang datang, pengaturan lalu lintas, memberikan sosialisasi dan edukasi melalui pesan tertulis di spanduk atau baliho sebagai bagian dari kampanye komunikasi kesehatan. Meskipun juga dari beberapa pihak pendukung tersebut tidak serta merta melakukan pemantauan di lapangan secara berkala.

Para pengelola di objek wisata Taman Sungai Mudal tidak hanya menjadi satuan dari penyelenggara wisata yang sifatnya informatif saja, melainkan juga sifatnya partisipatif. Pengelolaan objek wisata di Taman Sungai Mudal pada masa adaptasi kebiasaan baru sesungguhnya tidak terlepas dari keterlibatan partisipasi masyarakat secara langsung maupun tidak langsung. Gerakan Masyarakat Sadar Wisata/MASDARWIS menjadi tumpuhan untuk mewujudkan sumber daya manusia yang siap, berwawasan dan terbekali dalam melayani calon wisatawan sehingga dapat saling memperdayakan antara satu dengan yang lain ataupun mampu menjadi "Leader of Business" di masa sekarang serta masa yang akan datang.

Membangun masyarakat yang sadar wisata sebenarnya juga menjadi bagian dari rangkaian kegiatan sosialisasi oleh pemerintah. Persiapan MASDARWIS itu sendiri dapat dikolaborasikan dengan adanya penghargaan yang didapatkan Kabupaten Kulon Progo sebagai salah satu dari sepuluh desa wisata terbaik yang ada di Indonesia. Pernyataan tersebut bahkan diumumkan secara langsung oleh akun Kementerian Pariwisata dan Ekonomi Kreatif tahun 2021 (sumber: instagram @ kemenparekraf.id, 2021).

Sehingga berdasarkan hal tersebutlah, mematangkan sumber daya manusia menjadi kunci utama keberhasilan dalam meuwujukan pariwisata yang unggul dan berkelanjutan di masa sekarang serta masa yang akan datang. Tercapainya pengembangan sektor pariwisata yang berkelanjutan nantinya tidak hanya berorientasi kepada nilai ekonomi yang dihasilkan, melainkan juga kesejahteraan yang diperoleh dan dapat diwariskan dari waktu ke waktu.

Tata kelola adaptasi kebiasaan baru di objek wisata Taman Sungai Mudal pada prinsipnya sudah dilakukan penyesuaian meskipun masih belum begitu maksimal. Pemerintah sebagai salah satu bagian dari stakeholders pariwisata harus berperan ganda, yang tidak hanya membuat regulasi untuk mengatur kegiatan pariwisata dengan himbauan penerapan protokol kesehatan, namun juga dapat mengevaluasi pelaksanaan kegiatan tersebut sebagai salah satu langkah strategis yang berorientasi terhadap keselamatan bersama.

Merefleksi 1 tahun kehadiran Virus Corona di Indonesia, ada banyak infodemik yang tidak akurat, tidak sinkron, dan sangat membingungkan, sehingga dalam pengelolaan objek wisata Taman Sungai Mudal juga sangat diperlukan proses sosialiasi dari dinas terkait baik di tingkat kabupaten maupun di tingkat provinsi. Kegiatan sosialisasi dijadikan sebagai pedoman oleh para pengelola untuk melaksanakan dan mencapai keberhasilan membuka 
kembali objek wisata dengan tetap mencerminkan unsur kesehatan serta keamanan terhadap para pengunjung di masa adaptasi kebiasaan baru sekarang ini. Namun kenyataannya dalam perjalanan sejak tahun 2020-2021, para pengelola di lokasi wisata tersebut hanya sekali saja mendapatkan kegiatan sosialiasi yang sebenarnya adalah sebuah keharusan.

Minimnya bantuan pendanaan atau anggaran dari pemerintah kabupaten ataupun pemerintah provinsi untuk melengkapi keperluan logistik di masa adaptasi kebiasaan baru yang kondisinya tidak sama dari biasanya, menuntut para pengelola yang ada untuk tidak bergantung dan berusaha lebih giat lagi dalam memasarkan destinasi wisata tersebut.

Di sisi lain, ada segenap rangkaian mitigas di tengah pandemi saat ini, seperti program vaksinasi yang juga merupakan salah satu upaya pemerintah untuk mengembalikan keseimbangan perekonomian masyarakat termasuk untuk para pelaku usaha di bidang pariwisata. Lagi dan lagi dalam hal ini para pengelola di objek wisata Taman Sungai Mudal pun masih belum bisa mendapatkan fasilitas tersebut.

Peradaban teknologi yang semakin pesat salah satunya dengan kehadiran media sosial turut mempengaruhi minat khusus berwisata para pengunjung di objek wisata Taman Sungai Mudal. Aktivitas pengguna media sosial yang sekarang ini jauh yang lebih modern dan adiktif membuat berbagai konten visual menjadi sumber utama para pengunjung untuk mendapatkan informasi secara lebih personal, lebih profesional atau bahkan lebih global (Ningrum, 2019).

Dampak positif dari berkembangnya teknologi komunikasi yang terjadi di masyarakat sebagai contoh adalah semua orang dapat menjadi sumber informasi sehingga membuat masing-masing dapat saling bertukar informasi dengan cara berkomunikasi (Kristiyono, 2015). Dokumentasi para pengunjung yang dipublikasikan oleh para pengelola di objek wisata Taman Sungai Mudal khususnya melalui pengalaman beberapa publik figur yang sempat datang ke lokasi tersebut, dianggap sebagai sebuah rekomendasi yang menarik dibandingkan dengan beberapa teks promosi dimasa lampau. Kehadiran media sosial sebagai media massa baru saat ini memberi kemudahan masyarakat bisa langsung memberikan umpan balik terhadap informasi-informasi yang disampaikan, terutama media massa yang melakukan konvergensi. Termasuk salah satunya konten yang disampaikan pada media sosial Taman Sungai Mudal (Gushevinalti, et al.2020).
Disamping itu, ada strategi lainnya yang sengaja disiapkan oleh para pengelola di objek wisata Taman Sungai Mudal terkait fasilitas wifi internet yang segmennya sendiri untuk menggencarkan publikasi para pengunjung ketika berada di lokasi tersebut, terutama di beberapa media sosial, khususnya instagram.

Bahkan saat ini pemerintah tengah mengembangkan JARINGAN PARIWISATA HUB/JP HUB (sebuah terobosan baru berdasarkan kebutuhan milenial). Yang mana seluruh kebutuhan informasi wisawa Indonesia mulai dari tingkat daerah hingga provinsi seluruhnya akan tersedia. Selain itu, pemesanan paket perjalanan pun dapat langsung dilakukan dengan platform tersebut. Dengan demikian diharapkan dapat mensukseskan dan mendukung juga lokomotif promosi produk lokal sebagai pintu pengetahuan, pencarian dan pemesanan kesatuan paket wisata.

Agar dapat bertahan di tengah krisis pandemi, para pengelola objek wisata di Taman Sungai Mudal juga harus memperhatikan tingkat kepuasan para pengunjung yang datang, salah satunya dengan merespon beberapa macam saran yang masuk khususnya permasalahan sampah bekas yang cukup mengganggu kebersihan lingkungan di ekowisata ini dan bertentangan dengan panduan CHSE di fase kebiasaan baru. Super penting bagi pemerintah untuk memberikan training/pelatihan kepada para pengelola, misalnya dalam hal mewajibkan para pengunjung/calon wisatawan untuk membawa botol minum, tumblr, dan sedotan sendiri agar terbebas dari sampah plastik dan bentuk kotoran bekas pakai lainnya.

Tidak ketinggalan, dalam mendukung kebijakan terbaru Pemerintah Daerah berdasarkan Surat Edaran Gubernur DIY No.29/2021 tentang Memperdengarkan Lagu Kebangsaan Indonesia Raya, termasuk di objek wisata Taman Sungai Mudal telah ditindaklanjuti oleh para pengelola walaupun dengan cara yang amat sederhana. Kehadiran para pengunjung setiap harinya bahkan sangat berdampak terhadap pendapatan masyarakat lokal yang menumpuhkan hidupnya di lokasi wisata tersebut. Diharapkan kolaborasi dan kerjasama dari semua lini untuk terus menghidupkan kegiatan pariwisata di Yogyakarta khususnya sebagai salah satu deretan destinasi wisata super prioritas

\section{SIMPULAN}

Keberlangsungan tata kelola adaptasi kebiasaan baru di objek wisata Taman Sungai Mudal memang terlihat lemah karena komitmen pihak pemerintah 
maupun mitra yang belum cukup terintegrasi dengan baik dan bahkan tingkat kesadaran terhadap pelaksanaan protokol kesehatan dari para pengelola serta pengunjungnya sendiri masih sangat minim. Mengembangkan partisipasi dan dukungan dari para pemangku kebijakan sejatinya mendorong iklim berwisata yang kondusif dalam perencanaan pembangunan pariwisata yang unggul disuatu wilayah tentu dengan penguatan protokol kesehatan disetiap aktifitasnya.

Melalui partisipasi masyarakat di suatu kawasan objek wisata lah, akan menentukan tujuan pencapaian kegiatan berwisata yang sehat dan bersih di masa sekarang. Menggunakan masker saat ini adalah keputusan dan kesadaran individu termasuk mencuci tangan dengan air yang mengalir, tetapi menjaga jarak seharusnya sudah menjadi keputusan bersama. Apabila ada individu yang berinteraksi/berkomunikasi dengan orang lain dengan melepas masker sebagai kewajibannya, maka lawan bicaranya harus dapat menjauh agar tetap menciptakan jarak yang ideal.

Filterisasi jumlah kunjungan wisatawan menjadi faktor penting keberhasilan membuka kembali objek wisata, terutama di kawasan wisata air. Sangat dibutuhkan koordinasi secara terpadu khusunya dari pemerintah terhadap para pelaku wisata yang sesuai dengan kebijakan penerapan protokol kesehatan di masa adaptasi kebiasaan baru sekarang ini.

\section{DAFTAR PUSTAKA}

Ajak Warga Disiplin Protokol Kesehatan. (2020). https://www.liputan6.com/news/read/4371916/a jak-warga-disiplin-protokol-kesehatan-satgascovid-19-kampanyekan-ingat-pesan-ibu.

Dinas Pariwisata Kulon Progo. (2020). Ekowisata Sungai Mudal. https://dinpar.kulonprogokab.go id/ekowisata-sungai-mudal.html

Gunia, A. (2020). Will the Coronavirus Ever Go Away? Here's What One of the WHO's Top Experts Thinks. Retrieved June 2, 2020, from https://time.com/5805368/willcoronavirus-goaway-worldhealth-organization/

Gushevinalti, G., Suminar, P., \& Sunaryanto, H. (2020). Transformasi Karakteristik Komunikasi Di Era Konvergensi Media. Bricolage: Jurnal Magister Ilmu Komunikasi, 6(01), 083-099.

Hassan Shadily, 2001, Sosiologi untuk Masyarakat Indonesia, Jakarta: PT Rineka Cipta.

I Made Wirartha (2006:39) Wirartha, I Made. 2006. Metode Penelitian Sosial Ekonomi. Yogyakarta: Andi Offset.
Keputusan Menteri Kesehatan Nomor: HK.01.07/ Menkes/382/2020. Tentang Protokol Kesehatan Bagi Masyarakat di Tempat dan Fasilitas Umum Dalam Rangka Pencegahan dan Pengendalian Corona Virus Disease 2019 (COVID-19). KEMENKES RI

Krisdayanthi, A. (2020). New Normal Pariwisata Bali di masa Pandemi pada Daerah Tujuan Wisata Tanah Lot, Kabupaten Tabanan. Pariwisata Budaya: Jurnal Ilmiah Agama Dan Budaya, 5(2), 49-56.

Kristiyono, J. (2015). Budaya Internet: Perkembangan Teknologi Informasi Dan Komunikasi Dalam Mendukung Penggunaan Media Di Masyarakat. Scriptura, 5(1), 23-30.

Mulyana, Deddy. 2010.Metode Penelitian Kualitatif. Bandung: PT Remaja Rosdakarya

Ningrum, D. P. (2019). Pemanfaatan Media Sosial Terhadap Fenomena "Hoax" Di Kalangan Remaja Milenial (Studi Di SMAN 1, Kecamatan Pleret, Bantul, Yogyakarta). Jurnal Ilmiah Padma Sri Kreshna, 1(1). https://doi.org/10. 37631/psk.v1i1.35.

Ningrum, D. P., Adhrianti, L. \& Gushevinalti (2018). Strategi Komunikasi Pariwisata Kota Bengkulu Studi Unique Selling Proposition Program Visit 2020 Wonderful Bengkulu. Journal Communication Spectrum, 8(1), 45-55. http://doi.org/10. 36782/jcs.v8i1.1811

Nugroho, R. (2018). Kebijakan Periwisata sebuah pengantar untuk negara berkembang. Yogyakarta: Pustaka Pelajar.

Situmeang, I. V. O. (2020). Strategi Komunikasi Pariwisata: Menciptakan Seminyak Menjadi Top of Mind Tujuan Wisata di Bali. Scriptura, 10(1), 43-52.

Sugiyono. 2013. Metode Penelitian Kuantitatif Kualitatif dan $R \& D$. Bandung: Alfabeta.

Sumarni, S. (2020). Implementasi kebijakan Kementerian Pariwisata dan ekonomi kreatif dalam menghadapi adabtasi kebiasaan baru di bidang pariwisata study kasus di Kabupaten Gunungkidul. The International Seminar on Regional Politics, Administration and Development 2020 (INSORPAD2020), STISIPOL Raja Haji, Riau, INDONESIA.

Slamet. 2003. Pembangunan Masyarakat Berwawasan Partisipasi, Surakarta: Sebelas Maret University Press.

Taman Sungai Mudal. (2020). https://www.datawisata.com/taman-sungai-mudal-kulon-progo.

Teguh, M., \& Ciawati, S. T. (2020). Perancangan Strategi Digital Marketing Communication Bagi Industri Perhotelan dalam Menjawab Tantangan Era Posmodern. Bricolage: Jurnal Magister Ilmu Komunikasi, 6(01), 051-064. 